NBER WORKING PAPER SERIES

\title{
HISTORICAL FINANCING OF SMALL- AND MEDIUM-SIZED ENTERPRISES
}

\author{
Robert Cull \\ Lance E. Davis \\ Naomi R. Lamoreaux \\ Jean-Laurent Rosenthal \\ Working Paper 11695 \\ http://www.nber.org/papers/w11695
}

\author{
NATIONAL BUREAU OF ECONOMIC RESEARCH \\ 1050 Massachusetts Avenue \\ Cambridge, MA 02138 \\ October 2005
}

The views expressed herein are those of the author(s) and do not necessarily reflect the views of the National Bureau of Economic Research.

(C)2005 by Robert Cull, Lance E. Davis, Naomi R. Lamoreaux, and Jean-Laurent Rosenthal. All rights reserved. Short sections of text, not to exceed two paragraphs, may be quoted without explicit permission provided that full credit, including (C) notice, is given to the source. 
Historical Financing of Small- and Medium-Sized Enterprises

Robert Cull, Lance E. Davis, Naomi R. Lamoreaux, and Jean-Laurent Rosenthal

NBER Working Paper No. 11695

October 2005

JEL No. G2, N2

\begin{abstract}
We focus on the economies of the North Atlantic Core during the nineteenth and early twentieth centuries and find that an impressive variety of local financial institutions emerged to supply the needs of SMEs wherever there was sufficient demand for their services. Although these intermediaries had significant weaknesses, they were able to tap into local information networks and so extend credit to firms that were too young or small to secure funds from large regional or national institutions. In addition, by raising the return to savings for local households, they helped to mobilize significant new resources for economic development.

Robert Cull

The World Bank

rcull@worldbank.org

Lance E. Davis

Humanities and Social Sciences

California Institute of Technology

1200 East California Boulevard MC 228-77

Pasadena, CA 91125

and NBER

led@hss.caltech.edu

Naomi R. Lamoreaux

Department of Economics

UCLA

405 Hilgard Avenue

Los Angeles, CA 90095-1477

and NBER

lamoreaux@econ.ucla.edu

Jean-Laurent Rosenthal

UCLA

rosenthal@econ.ucla.edu
\end{abstract}




\section{Historical Financing of Small- and Medium-Size Enterprises*}

\section{Introduction}

The size distribution of firms in developing nations today is very different from that in most advanced economies. In the poorest countries on average almost two thirds of workers are employed in very small (micro) enterprises- that is, enterprises with less than five employees — and most of the rest work for large firms with more than one hundred employees. Small- and medium-size firms have little presence in these economies and together employ on average less than 10 percent of the total workforce. By contrast, in the richest countries more than two thirds of all employees work for large enterprises, the bulk of the remainder work for small- and medium-size enterprises (SMEs), and only a very small fraction for micro enterprises (Snodgrass and Biggs, 1996). Although large firms account for the lion's share of aggregate economic activity in most developed countries, SMEs play a more significant role than their proportion of total employment might suggest. Not only do they make up the vast majority of firms, but they dominate many sectors of economic activity and have been an ongoing source of new products and of technological innovation more generally.

\footnotetext{
* We would like to thank Thorsten Beck, Asli Demirgüç-Kunt, Kenneth Sokoloff, two anonymous referees, and participants in the World Bank Conference on Small and Medium Enterprises for their helpful comments. We are also grateful to our research assistant, Andrea Maestrejuan. The findings, interpretations, and conclusions expressed in this paper are entirely those of the authors. They do not necessarily represent the views of the World Bank, its Executive Directors, or the countries they represent.
} 
A common explanation for the comparative absence of SMEs in poor countries today is that they cannot obtain access to capital. As a survey recently conducted by the World Bank confirms, large firms everywhere generally have more access to bank credit, both local and foreign, than small firms, whereas the latter rely heavily on internal funds and retained earnings. ${ }^{1}$ Nonetheless, the survey also indicates that there is considerable heterogeneity across countries in the sources of finance for SMEs, with the share of small firms that have no external finance ranging from 19.2 percent in Croatia to 72.9 percent in Armenia (see Table 1). In about a quarter of the countries small firms obtain more than ten percent of their funds from trade credit, and in about 40 percent they obtain an equivalent share from local commercial banks. In general, moreover, the countries in which SMEs have access to these kinds of external sources are those with more advanced financial systems, suggesting there may have been a causal relationship between financial development and the viability of SMEs. ${ }^{2}$

Such a possibility is also consistent with the recent literature on financial development and economic growth. Based on cross-country regressions, this literature suggests that there is a strong positive association between the extent of a country's

\footnotetext{
${ }^{1}$ The surveys of funding sources for businesses were conducted under the World Bank investment climate program in 2002-2003 in 38 developing countries in Europe, Asia, Africa, and Latin America. See http://research.worldbank.org/ics/jsp/index.jsp for details. Hereafter we refer to them as Investment Climate Surveys (ICS).

${ }^{2}$ Further evidence on this point comes from Beck, Demirgüç-Kunt, and Maksimovic (2004), who use a different cross-country database to control for additional firm characteristics and find that small firms and those in countries with poor institutions use less external finance than other enterprises.
} 
financial development and its growth rate, and that the direction of causation runs from finance to growth rather than the reverse (Beck, Levine, and Loayza, 2000; Levine, Loayza, and Beck, 2000). There are strong theoretical reasons to believe these results, but they have not gone uncontested. The case-study evidence, in particular, has yielded more ambiguous conclusions. For example, commenting on a series of historical studies that aimed to pin down the relationship between financial and economic development, Rondo Cameron observed that the banking system seems merely to be "one of many institutions that impinge on the economy and affect its performance for better or worse" (Cameron, 1972, 6). ${ }^{3}$

We have no ambition in this article to challenge the idea that modern financial institutions are necessary for sustained economic growth. To the contrary, we sidestep this higher-order question entirely and instead use historical evidence to get a clearer sense of how SME's special financing problems have been resolved in different times and places. We focus our examination on what we call the North Atlantic Core-the countries of northern and western Europe and North America. Most of the economies in these regions developed the full panoply of modern financial institutions quite early in their history and then industrialized successfully over a period that stretched from the late eighteenth to the early twentieth centuries. ${ }^{4}$ There is no doubt that modern financial

\footnotetext{
${ }^{3}$ For excellent surveys of this literature that argue that the balance of the case-study evidence supports the finance-leads-development view, see Levine (1997 and 2005).

${ }^{4}$ They have also been extensively studied, but here it is important to interject a note of caution. Even in these cases, relatively little work has been done on the finance of SMEs, particularly little
} 
institutions were crucially important for the overall growth record of these economies, but it does not necessarily follow that they played a significant role in the finance of SMEs. Indeed, as we demonstrate in the following sections, the evidence points to precisely the opposite conclusion. SMEs in the North Atlantic Core rarely raised capital on the equity markets. Nor did they typically obtain credit from large financial-center banks. Although SMEs did tap external sources of funds to secure working capital, withstand adverse business conditions, and take advantage of new technologies and opportunities, they obtained this assistance from an impressive variety of local financial intermediaries. Moreover, these institutions seem to have emerged endogenously to meet their needs wherever there was sufficient demand.

To say that these institutions emerged in response to local demand is not to say that they followed rather than led economic growth. Rather, we mean to suggest that the entrepreneurs who hoped to make use of (and often helped to create) these institutions expected that access to finance would enable their firms to exploit potential markets that were otherwise beyond their reach. It is in this sense that the demand for these institutions preceded and in some sense "caused" economic growth. The bulk of our article is devoted to documenting the idiosyncratic, path-dependent processes that generated this diverse set of local financial intermediaries. As we show, governments did little to inhibit their formation, but they also played little role in their creation-beyond providing a secure property-rights environment and establishing national financial institutions, such as central banks, that helped to mitigate local shocks. Nor were

quantitative work. Hence much of what follows draws of necessity on qualitative evidence and on the histories of individual industries and firms. 
governments generally able to jumpstart economic growth by promoting local financial institutions in regions where there was insufficient demand for their services. Admittedly, the specialized intermediaries that emerged to meet SMEs' needs had significant weaknesses, but they were able to tap into local information networks and hence extend credit to firms that were too young or small to secure funds from large regional or national institutions. Moreover, by raising the return to savings for households in their vicinity, they helped to mobilize significant new resources for economic development.

\section{Equity Finance}

Formal securities markets emerged throughout the North Atlantic Core well in advance of industrialization. Despite their early appearance, however, they played relatively little role in the finance of SMEs. Although initially organized to facilitate trading in long-term government debt, the types of securities they handled expanded steadily over time - first to include privileged trading corporations, then other companies promoted by the state (mainly in finance, transportation, and utilities), and then private companies more generally. Nonetheless, as late as the end of the nineteenth century, it was still comparatively rare for manufacturing or other non-infrastructural firms to be listed on the exchanges. Even in the first third of the twentieth century only the securities of the very largest companies traded (Gelderblom and Jonkers, 2004; Mitchie, 1999; Plache, 1999; Hautcoeur, 1994; Navin and Sears, 1955; Baskin and Miranti, 1997; Franks, Mayer, and Rossi, 2005). 
To some extent, of course, trading in manufacturing and other similar securities was inhibited by information problems. Investors were more willing to put their funds in sectors like railroads where the capital stock was highly visible or in finance where government regulators at least to some extent served as monitors. But information problems cannot be the whole story. Certainly, there were markets where intermediaries were in a position to signal the quality of new issues to investors. For example, Paris had an active curb market (the Coulisse), supported by a large and competitive group of private banks that specialized in collecting information about, and underwriting the equity issues of, firms who wanted to raise capital (Plache, 1999; Hautcoeur, 1994; Thomas, 1973, ch. 6-7). Throughout the North Atlantic Core, moreover, there were regional exchanges that handled the securities of firms whose entrepreneurs and business activities were well known to local investors. Even in these settings, however, the number of different manufacturing securities actually traded was still quite small relative to the potential amount. For example, in the 1890 s the Boston market quoted stock prices for only about a hundred manufacturing firms, though thousands of industrial corporations had been chartered in the New England region. According to a broker who maintained a record of trading, manufacturing stocks generally were held by people who did not intend to sell them. As a result, "it was exceedingly difficult to obtain reliable quotations," even for the region's largest enterprises, because the securities rarely appeared on the market “except in stray shares or in the case of executors” sales" (Martin, 1898, 126-32).

Not only did manufacturing securities tend to be closely held, but the vast majority of companies took organizational forms that did not yield tradable shares. At first, of course, there was little choice in the matter because the only available form for a 
multi-owner enterprise was the partnership. But even after the third quarter of the nineteenth century, when the corporate form became widely available by registration, most businesses did not avail themselves of the possibility to issue shares. In order to understand why, it is helpful to get some sense of the tradeoffs involved in the choice of organizational form. The partnership, of course, had serious drawbacks. All members had unlimited liability, but they also possessed full ownership rights. Hence, they could enter into contracts that were binding on the firm without consulting the other partners, so long as the contracts were in the scope of the firm's normal business activities. Not only did this right to act unilaterally mean that partners faced obligations that they might not even know about, it was a potential source of conflict within the firm. As a result, partnerships suffered from the nontrivial probability that otherwise profitable ventures would suffer costly dissolution. Not surprisingly, they tended to be formed among individuals who knew each other well—that is, who had some kind of deeper personal relationship that could form a basis for trust (Lamoreaux and Rosenthal, 2006). Although corporations solved the most pressing problems of partnerships, they did so by making controlling shareholders effectively dictators. Hence corporations also had important drawbacks because majority shareholders could use their power to benefit themselves at the expense of other members of the firm. Although the latter were only limitedly liable for the enterprise's debts and thus, in the event of insolvency, stood to lose no more than their investments, they had to worry about the possibility that controlling shareholders would expropriate a significant share of their returns. As a result, corporations also required a high degree of trust among members of the firm (Lamoreaux and Rosenthal, 2006). 
In France and elsewhere on the European continent, the provisions of the commercial code allowed business people to contract around some of the problems of partnerships. For example, one or more members of the firm could exchange their control rights for limited liability. It was also possible for members to restrict the extent to which their partners could act unilaterally or even prevent them from encumbering the firm. Not surprisingly, in both absolute and relative terms, many fewer SMEs chose to organize as corporations on the continent than in Britain or the U.S., where such options either were not permitted or not as well enforced (Lamoreaux and Rosenthal, 2005). An even more attractive alternative became available over time, moreover. The new form appeared first in Germany, where the government had designed the corporate form with large enterprises in mind and had set particularly high minimum share values and capital requirements. The government had envisioned that SMEs would continue to be organized as partnerships of one type or another, but the obvious contracting problems associated with these forms led it to provide entrepreneurs (in 1892) with an alternative form of organization - the private limited liability company (Gesellschaft mit beschränkter Haftung, or $\mathrm{GmbH}$ ). A hybrid between partnerships and corporations in which share capital was not tradable but all owners had limited liability, the GmbH helped business people overcome the contracting problems associated with both of these forms and quickly became the device of choice for medium-sized enterprises in Germany (Lamoreaux and Rosenthal, 2005; Pohl, 1991).

Other European countries followed suit in the early twentieth century. The British Parliament passed a statute enabling businesses to organize as private limited liability companies in 1907, and France created the société à responsabilité limitée 
(SARL) in 1925. In both countries large numbers of medium-sized companies immediately adopted the new form. Indeed, as Figure 1 shows, in France the overwhelming majority of new multi-owner firms chose to organize as SARLs (Lamoreaux and Rosenthal, 2005). Portugal passed similar legislation as early as 1911, Austria in 1916, and most other western European countries by the mid-1930s (Lehnardt, 1955, 16-19). The form was enormously popular wherever it was available, and as a result SMEs in these countries rarely organized in ways that permitted them to issue tradable shares.

The one big exception to this story was the U.S., where effective legislation for private limited liability companies (LLPs and LLCs) was not passed until the end of the twentieth century, and where even then the take-up rate for the form was slow (presumably because there had been adjustments in the interim that made the corporate form more useful to SMEs). Even in the U.S., however, the ongoing need for members of a corporation to have a high degree of trust meant that entrepreneurs raised investment capital mainly by means of personal connections. To this very day, shares in the vast majority of corporations never trade on the market (Lamoreaux and Rosenthal, 2005).

\section{Debt Finance}

Historical studies of the role of banks in industrial finance have long focused attention on what are called "universal banks" - that is, institutions that provided both commercial and investment banking services to their customers. Many scholars have argued that this combination of activities gave universal banks advantages in obtaining information about customers that enabled them to play an important role in financing 
economic development (Tilly, 1986 and 1989; Benston, 1994; Calomiris, 1995;

Guinnane, 2002). This claim has occasioned much debate, but whether one agrees with it or not, it is doubtful that universal banks-or for that matter any other financial center banks_-extended much in the way of credit to SMEs.

Although private banks had long provided a mix of commercial and investment services to their customers, the term universal bank is usually reserved for the large incorporated financial intermediaries that emerged in Europe during the second half of the nineteenth century, especially in Germany (Riesser, 1911; Gerschenkron, 1962; Tilly, 1966; Calomiris, 1995; Da Rin, 1996; Guinnane, 2002). ${ }^{5}$ While there is no denying that the great German banks lent money to and underwrote the securities issues of important industrial ventures, studies of specific German industries have found considerable heterogeneity in the extent to which firms made use of universal banks' services. ${ }^{6}$ More

\footnotetext{
${ }^{5}$ Many scholars have argued that such institutions did not develop in Anglo-American countries, where banks were much more conservatively focused on the commercial side of their business and were much less involved in industrial finance (Best and Humphries, 1998; Kennedy, 1987; Calomiris, 1995). In recent years, however, these generalizations about the differences between German and Anglo-American banking have been vigorously challenged. See especially Collins (1991 and 1998); Capie and Collins (1992); and Fohlin (1997a, 1997b, 1998, 1999a and 1999b).

${ }^{6}$ For example, iron and steel firms were heavily dependent on banks during the difficult 1870s and 1880s. By the 1890 s, however, they were in a position to finance investment largely out of retained earnings, and had begun systematically to reduce the extent of their ties to particular financial institutions. The role that banks played in the organization of electrical utilities is generally acknowledged, but it is thought that banks' presence was comparatively negligible in the country's flagship chemical industry (Pohl, 1984; Feldenkirchen, 1981 and 1991; Wengenroth, 1994; Wellhöner and Wixforth, 2003).
} 
importantly, the number of companies that were in a position to take advantage of the banks' combination of investment and commercial banking services was in fact quite small (Tilly, 1986, 1989, and 1992). In 1905, nearly 2000 companies were listed on the various German exchanges. These companies constituted 36 percent of all joint-stock corporations (Fohlin, 1999b, 328), but joint-stock companies themselves accounted for a relatively small portion of industrial investment in Germany-less than 20 percent of the total in the first decade of the twentieth century (Edwards and Ogilvie, 1996, 436-37). As we have seen, most multi-owner enterprises in Germany (and elsewhere in Europe) were organized as partnerships or private limited liability companies - that is, as enterprises that could not issue tradable securities. Hence, to the extent that universal banks provided any assistance to these firms, it was mainly in the form of credit, especially short-term commercial lending on current account.

There are good theoretical reasons to believe, moreover, that large financial center banks, whether they were in Berlin or London or Paris or New York, were unlikely to be important sources of credit for SMEs. These kinds of institutions were costly to set up and hence were geared to serving the needs of customers for whom the volume of activity justified the costs of acquiring information about the firm's prospects and ability to repay. Even if one assumes that the cost of ascertaining creditworthiness was not a decreasing function of the borrower's size and number of years in operation, the cost to the bank per dollar loaned would be greater for SMEs than for large-scale enterprises. Of course, if the cost of checking the credit of an SME was higher, the situation was even worse. Moreover, the difficulties were likely to be still greater for SMEs located outside the main financial centers. To avoid problems of adverse selection, financial center banks 
would have to invest in developing the capacity to screen borrowers locally, but in small markets the benefits would not be worth the costs. There would also likely be competition from local intermediaries that had better access to information from informal personal connections. Indeed, in location after location throughout the North Atlantic Core, wherever there was a significant demand for these kinds of loans, intermediaries emerged in some form or another that were able to tap into local information networks and provide credit to SMEs.

Both the types of local intermediaries and the circumstances under which they developed varied enormously from one location to the next. On the European continent, for example, notaries came to play a pivotal role in the provision of credit. The primary responsibility of these officials was to draw up contracts for private individuals, and, because anyone who contested the contracts they drafted bore a heavy burden of proof, important agreements were almost invariably notarized. Notaries were thus in a position to acquire detailed information about the business activities and financial standing of their clients— to know who had idle wealth, who needed capital, and how individuals had performed in past transactions. In other words, they had the knowledge they needed to judge both a borrower's creditworthiness and a lender's ability and willingness to bear risk (Hoffman, Postel-Vinay, and Rosenthal, 2000).

Already, by the late seventeenth century, Parisian notaries had expanded beyond their simple duties as scriveners to take on the role of asset brokers, using the information they accumulated about clients to match borrowers and lenders. By the 1820 s, they were helping to raise capital for industrial enterprises, and some were moving into full-fledged underwriting. Outside Paris, notaries assisted industrial enterprises mainly by facilitating 
loans, but in Paris, the names of notaries appeared, alongside those of bankers and brokers, on tombstone advertisements soliciting investors in industrial share commandites in the 1830s (Hoffman, Postel-Vinay, and Rosenthal, 2003 and 2004). ${ }^{7}$

Although notaries' activities as financial intermediaries took them far beyond their original function and, at times, threatened the legitimacy of their position of public trust, the state was loath to intervene. Notaries who strayed into banking failed with some regularity during the early nineteenth century, but the government tolerated these transgressions until a formal banking system was well developed. Only then did it begin to clamp down. In Paris, not surprisingly, the end came sooner than elsewhere. The city already had more than 200 banks, as well as an established securities market, by the late 1830s when the bankruptcy of Jacques François Lehon spurred government action. Lehon's failed attempts to underwrite securities issues for a number of share commandites, and his subsequent fraudulent efforts to cover his losses, wiped out the assets of a large number of wealthy and well-connected depositors. ${ }^{8}$ Threatened with regulation, including periodic audits of their books, the Parisian notaries agreed to exit all banking activities and to police themselves to make the agreement stick (Hoffman, Postel-Vinay, and Rosenthal, 2003). In the countryside, however, notaries ignored the

\footnotetext{
${ }^{7}$ A commandite was a partnership with one or more managing partners who bore full liability for
} the enterprise's debts and one or more silent partners who had limited liability. During the 1830s, some of the largest commandites began to make the silent partners' shares tradable. In this way, they created an early substitute for the still difficult-to obtain corporate form. See Lamoreaux and Rosenthal (2005).

${ }^{8}$ The judicial proceedings against Lehon can be followed in the pages of the Gazette des Tribunaux from January of 1841 to June of 1842. See also Hoffman, Postel-Vinay, and Rosenthal (2003). 
government's threats, and it was not until the 1890s that the state required them to halt their financial activities. By then, however, the number of banking offices outside Paris had grown to 2,500 or so (from about 800 in the 1830 s), and there were also more than 1,000 savings bank branches. ${ }^{9}$

In Anglo-American countries, notaries did not play such an important role in drafting contracts and so did not have the same privileged access to information as their counterparts on the European continent. But there were other ways to harness local information to facilitate the provision of credit to SMEs. By the middle of the nineteenth century, for example, credit reporting agencies had emerged in the United States to collect local information and sell it to businesses that needed to decide whether or not to extend trade credit (and how much) to firms in other parts of the country. The most successful such enterprise was the Mercantile Agency, predecessor of Dun and Bradstreet. The Mercantile Agency developed a network of correspondents in communities across the country who were paid to send the company regular reports on the standing of local businesses. Lawyers were especially well-placed to perform this function because a mainstay of their business during this period was the collection of unpaid debts. For firms that had not defaulted on any payments, correspondents reported what they could learn from interviews, newspapers, local records, and gossip about the wealth and character of proprietors and the volume and profitability of their businesses. As in the case of notaries, the response of government to this innovation was generally permissive. State legislatures resisted pressure to make agencies liable for losses when

\footnotetext{
${ }^{9}$ Annuaire Didot-Bottin, various years.
} 
their subscribers acted on misinformation, and the courts were similarly unwilling to make this business unprofitable. Although for a time there was some uncertainty about whether the courts would consider the dissemination of unfavorable information to be grounds for a libel suit, the trend was to require only that credit report agencies be reasonably diligent (Madison, 1974; Norris, 1978; Olegario, 2001; Balleisen, 2001). More generally, the marginal role played by notaries in the Anglo-American world increased the relative importance of local banks in the provision of credit to SMEs. In England, for example, there was a dramatic expansion in the founding of "country" banks during the early industrial period, with the number increasing from 12 in 1750 to over 300 by 1800 . These banks were partnerships, limited by law to no more than six members. Many were formed by industrialists with the express purpose of providing financial support for their manufacturing enterprises. Most of this support came in the form of short-term credit, but banks in some areas also provided medium- and long-term loans. In 1825, new legislation permitted banks to organize as joint-stock companies, but those that adopted the new form seemed to have changed their structure more than their function. The prominent position that local manufacturers continued to occupy on their boards suggests that the banks still served the interests of their directors (Cottrell, 1979, 14-16; Collins, 1991, 23-29; Newton, 1997).

Nowhere was the connection between local banks and local industry more apparent than in New England, the region of the United States that industrialized most rapidly during the first half of the nineteenth century. Particularly in Massachusetts and Rhode Island, charters for banking corporations were easy to obtain, and many entrepreneurs organized banks in their communities with the aim of providing themselves 
with a source of credit. It was well known that the banks thus created lent the bulk of their funds to their own officers and directors, or to others associated with these personages in business, but these institutions nonetheless found it easy to attract investment funds from members of their surrounding communities. Although people with savings seem to have been reluctant to invest them directly in manufacturing enterprises, they eagerly bought (in the form of bank stock) what was in effect a share of the diversified investments of their community's most active entrepreneurs. To protect and encourage this flow of funds, banks developed governance systems that enabled the entrepreneurs that dominated them to cross monitor each other. Although each entrepreneur might, if unchecked, have succumbed to the temptation to lend too much of the bank's funds to himself, each entrepreneur also had an interest in protecting this valuable source of credit and so could be counted on to intervene to prevent one of his colleagues from undermining the solvency of the institution. This system seems to have worked remarkably well, for bank failures were infrequent and capital flowed into the banking sector, giving the region one of the most favorable ratios of bank capital to population in the world (Lamoreaux, 1994; Meissner, 2005).

Of course, banks that lent their funds disproportionately to insiders discriminated against other would-be borrowers in their localities. In the New England case, however, political pressures forced state governments to lower barriers to entry into banking to such an extent that virtually any group of entrepreneurs who wanted to could organize a bank. This policy undoubtedly limited the extent of the distortion even if it could not completely eliminate it (Lamoreaux, 1994). In other states, legislatures were less liberal in their chartering policies, but banks there seem to have made an effort to prevent such 
political pressures from mounting by extending credit to significant numbers of outsiders, many of them small, local manufacturers. In order to do this safely, they exploited local sources of information, assiduously investigating the reputations of those who applied to them for credit and maintaining detailed records of the financial tidbits they gleaned. When bank officers themselves did not know a borrower, they relied on the judgment of someone they trusted who did. For example, the records of the Bank of Newburgh, New York, contain letters from a prominent local businessman recommending that the bank extend credit to particular farmers and tradesmen (Wright, 1999; Bodenhorn, 2000 and 2003).

Another type of local institution emerged in Germany to provide loans to small businesses and farmers: the credit cooperative (Guinnane, 2002; Herrigel, 1996; Wengenroth, 1999). There were several distinct movements to organize cooperatives during the nineteenth century, and the reformers who led these movements had somewhat different ideas about how these institutions should be organized. Nonetheless, all mobilized local information flows in essentially the same way-by inducing members who knew each other well to monitor each other's borrowing and enforce repayment terms. Cooperatives associated with the ideas of Freidrich Raiffeisen and Wilhelm Haas were primarily rural and saw their purpose to be the provision of long-term credit to farmers. Those associated with Hermann Schulze-Delitzsch tended to be located in urban areas and to lend short-term to small craftsmen and shopkeepers. Although rural cooperatives were by far more numerous, urban cooperatives tended to be much larger. In 1910 , for example, there were 15,517 cooperatives located in rural areas, compared to only 2,103 in urban, but despite their much greater numbers, rural cooperatives only had 
about twice as many total members as urban (Guinnane, 1997, 2001 and 2002; Ghatak and Guinnane, 1999).

There was also a tremendous expansion in savings banks (Sparkassen) in Germany during the late nineteenth century. In Prussia alone, the number of Sparkassen increased from 234 in 1850 to 1191 in 1880 to 1711 in 1910, and by 1910 there were 3072 savings banks in the country as a whole (Guinnane, 2002, 84-85). For much of the period, government regulations inhibited the ability of Sparkassen to lend to local SMEs by limiting the kinds of assets in which savings banks could invest. Though Sparkassen were able to make loans to industrial firms by taking mortgages on real estate or, in Prussia, on the security of a second endorser, over time their investments gravitated toward urban mortgages and government securities. Indeed, many governments chartered Sparkassen for the express purpose of creating a market for their own bonds. As Timothy Guinnane has pointed out, however, much of the government debt that Sparkassen purchased was issued to finance infrastructural improvements that potentially benefited local businesses, for example, by lowering transportation costs (Guinnane, 2002, 85-89). Moreover, the spread of Sparkassen had a profound effect on the savings rate. As the numbers of these local institutions grew, the number of savings books held by individuals increased as well-in Prussia, from 3 to 32 per hundred people between 1850 and 1910, and in Saxony, from 5 to 66 per hundred. Between 1860 and 1913, the share of savings institutions in the total assets of financial intermediaries in Germany grew from 12 to 24.8 percent, and it is likely that this increase mainly resulted from net additions to the resources of the financial system, which itself grew from about 4 to 90 billion Marks (Guinnane, 2002, 81, 85; Goldsmith, 1969, Table D-9). 
Although the Sparkassen had some unique features, similar types of savings institutions were founded throughout the North Atlantic Core during the industrial era. Some, like the Sparkassen, invested mainly in government securities, but others played a more direct role in financing SMEs. In early-nineteenth-century New England, for example, savings institutions were often founded by the same entrepreneurs who controlled local banks. Sometimes they engaged in the same types of insider lending as the banks but more typically they facilitated this type of financing by investing heavily in the banks' stock (Lamoreaux, 1994). Regardless of the particular lending behavior of such institutions, however, there is good reason to believe that they helped to mobilize capital for economic development by raising the return to savings for households in their vicinity (Davis and Gallman, 1978). Certainly, their founding was associated with dramatic jumps in savings rates throughout the North Atlantic Core (Goldsmith, 1969).

\section{Path Dependence, Imperfect Substitutes, and Ongoing Problems}

Firms typically need different types of finance for different purposes and at different points in their life cycle. Hence the three main categories of finance-equity, long-term credit, and short-term credit—are often thought of as complements. But they could also substitute for one another, albeit imperfectly, as we will argue below. Firms took advantage of whatever type of finance was most available in their locality, which in turn depended on factor endowments, the nature of the legal system, the structure of government, and the particular solutions that local entrepreneurs happened to devise to meet their needs. As a consequence, the evolution of local financial institutions had a 
path dependent character that resulted in persistent differences across countries, and even across locations within countries, in the ways SMEs raised funds.

In France, for example, textile manufacturers in different parts of the country raised funds in strikingly different ways. In Alsace and in the Seine River Valley between Paris and Rouen, textile manufacturers frequently raised capital by selling equity, exploiting first the commandite form of organization and later the corporation, and relying on family and business connections to reduce the information problems involved in securing outside infusions of funds (Levy-Leboyer, 1964; Chassagne, 1991). By contrast, in the textile center around Lille, firms rarely had recourse to the equity markets. Most were either sole proprietorships or family partnerships, and they raised funds primarily by borrowing. Because families often accumulated large landholdings as part of their diversification strategies, they possessed the collateral necessary for longterm loans. In the early part of the century, these loans were typically arranged by notaries, but over time banks increasingly provided local manufacturers with this type of credit and also with short-term loans. Indeed, by the middle of the century, this area had one of the densest networks of banks, most of them private, in the country. The banks generally were run by individuals with close personal links to the main industries of the area and, as a result, had good sources of information about the creditworthiness of local borrowers (Hirsch, 1991; Bonnin, 2004; Lescure, 1999).

This mix of long-term and short-term debt prevailed throughout most of the rest of France, but Paris was an important exception. Although bankers sometimes took equity positions in medium-size firms by becoming silent partners, they rarely made long-term loans to manufacturers because the latter generally lacked the necessary 
collateral. Unlike the countryside, where real estate was widely dispersed, Parisian landholding was extremely concentrated (Daumard, 1973; Piketty, Postel-Vinay, and Rosenthal, 2005). Nearly all the inhabitants of the city were renters, and most commercial and industrial enterprises leased their workspace. Although renting reduced manufacturers' access to long-term loans, it also reduced their fixed capital requirements (Lemercier, 2003). ${ }^{10}$

To meet manufacturers' needs for working capital, Paris had an active short-term debt market. Because there was no legal requirement for borrowers and lenders to register commercial debt, this market is less readily visible to historians than the types of credit mediated by notaries. But there is abundant evidence of its existence, both in the records of the bankruptcy court and in the concerns about controlling these kinds of liabilities that pervade the governance agreements of new firms and, more generally, the whole business literature of the period. Much of this short-term lending took the form of trade credit, where longstanding business relationships between upstream and downstream firms kept informational problems to a minimum (Brennan, 1997). In addition, small investment banks also made short-term commercial loans in sectors where they had invested in accumulating knowledge about the local population of firms.

\footnotetext{
${ }^{10}$ In some industries, moreover, Parisian manufacturers were able to limit their need for fixed capital in other ways as well. For instance, Paris was a major producer of luxury commodities known as “articles de Paris." These goods were most often produced through a putting-out system, with artisans working alone or in small groups "en chambre." The artisans owned their own tools with the manufacturer supplying only inputs and designs.
} 
As the French case demonstrates, even within a common political and legal system and even within a single industry, firms' capital structures could vary considerably in ways that reflected the peculiarities of local history. Across countries with different types of political or legal systems, of course, the variation could be greater still. Indeed, our discussion has emphasized the diversity of the solutions that entrepreneurs throughout the North Atlantic Core devised to meet the financing needs of SMEs. Although some of these solutions presumably were better-that is, more efficient in channeling funds to promising projects—-than others, the important thing was that they arose in the first place. Over time, moreover, the efficiency of local financial institutions typically improved as the first movers evolved and/or as new intermediaries entered the market to replace or complement their predecessors. Thus in France the role of notaries in mediating lending declined as banks became important sources of credit. Similarly, by the late nineteenth century borrowers in the industrial regions of the U.S. were served by a whole panoply of formal financial intermediaries that ranged from large commercial banks and trust companies to smaller versions of the same types of institutions to even smaller savings and loans.

So long as firms had access to some form of finance, moreover, the particular type that was available—debt versus equity or short-term versus long-term credit—seems not to have mattered all that much. Hence industrialization progressed rapidly in New England during the early nineteenth century, despite firms' limited access to equity finance or long-term loans. The swelling ranks of local banks made credit available to SMEs in the form of 60- or 90-day notes that could be rolled over for extended periods of time and thus effectively substitute for long-term capital (Lamoreaux, 1994). The more 
capital-intensive firms that sprang up in the machine tool, electrical, and automobile industries in the Midwest during the second industrial revolution thrived on similar shortterm sources of funds. Indeed, their entrepreneurs were actively involved in founding local savings institutions and trust companies that would help them meet their financing needs in this way (Lamoreaux, Levenstein, and Sokoloff, 2006).

The extent to which equity and short- and long-term credit can substitute for each other should not, of course, be overstated. The different types of finance each serve some needs better than others. Short-term debt can expand and contract flexibly with the demand for working capital and so helps firms minimize their financing costs. Longterm debt and equity are more suitable for fixed-capital investments, the returns from which can only be realized over significant periods of time. Equity finance has implications for control rights that loans do not have, but missing interest payments can have much greater consequences for the survival of the firm than passing dividends.

Because SMEs historically have found it either preferable or easier to secure outside finance in the form of loans rather than investments of equity, they have tended to labor under relatively high burdens of (especially short-term) debt. Leverage and investment have both tended to increase during boom periods, and this pattern has generally meant large numbers of insolvencies during the downturns that inevitably ensued (Neal, 1994). The inefficiencies associated with this method of finance were clearly large, but industrialization nonetheless proceeded apace. Indeed, some scholars have argued that the creative destruction associated with this cyclical pattern helped to shift the economy's production possibility frontier outward, and that high failure rates 
may themselves have fostered an entrepreneurial spirit by removing the stigma associated with bankruptcy (Baten, 2001; Balleisen, 2001).

There is no question, however, that the financial institutions that emerged to serve SMEs were extremely vulnerable to shocks, such as crop failures, that affected the local economy. The credit cooperatives formed in Germany are particularly interesting in this regard because they experimented with formal means to solve this problem. These cooperatives were typically part of larger movements that also organized umbrella banks called "centrals" (owned collectively by the cooperatives in the movement and also sometimes by outside investors) that accepted deposits from member institutions, lent them money, gave them access to broader capital markets, and served as lenders of last resort. In 1895, the Prussian government chartered the Prussian Cooperative Central Bank (Preussenkasse) with capital supplied by the Prussian government to serve a similar function for all of the centrals located within Prussia (Guinnane, 1997 and 2002).

Throughout the North Atlantic Core, local banks and other local financial institutions attempted to improve their ability to withstand shocks by developing correspondent relationships with large urban banks. By placing funds on deposit with their urban correspondents, they could diversify their portfolios and secure access to credit in times of need. These arrangements never amounted to full insurance, however, because urban banks always exercised discretion about whether or not to provide additional resources to their client banks. Country banks often failed in England when money was tight, but nearly all paid their depositors in full when they were liquidated, suggesting that there would have been many fewer failures if the banks had been able to 
get through these periods of stringency. The rise of branch banking in England was in part an effort to solve this problem (Cottrell and Newton, 1999).

In Germany, another solution was for the large Berlin banks to acquire minority stakes in outlying institutions (Guinnane, 2002). These solutions are good examples of ways in which large banks that did not directly serve SMEs could assist the institutions that did lend to them and thus show how a well developed financial system could play important, if indirect, role in SME finance. That such assistance was not vital for the continued growth of the SME sector, however, is suggested by the case of the United States. Throughout the nineteenth and early twentieth centuries, regulatory restrictions meant that U.S. banks could only operate in a single state and, in most states, banks were not allowed to branch (Calomiris, 1995; Davis and Gallman, 2001). Small banks in the U.S. thus still had to rely of necessity on relations with correspondent banks to sustain them through periods of emergency.

Many nations also created central banks that could serve as lenders of last resort for the largest banks in the system, enabling them in turn better to perform their role of stabilizing smaller institutions. But these arrangements remained highly imperfect throughout our period, and financial crises continued to cause large numbers of bank failures. This imperfection was in turn a reflection of the quite limited role that governments in the North Atlantic Core played in the economy throughout our period. Beyond providing a secure property rights environment for transactions, governments for the most part left the financial system to its own devices. ${ }^{11}$

${ }^{11}$ To the extent that state intervention had negative consequences, moreover, it was more likely to affect large firms than SMEs. For example, the French government's regulation of access to the Bourse 
In addition to the vulnerability to shocks that resulted from SMEs' generally high levels of leverage, the informal nature of local credit markets meant that some degree of discrimination and hence credit rationing was inevitable. There is no doubt that individuals with thick ties to other members of their community, and with some capital of their own, were in a much better position to secure credit than other borrowers, regardless of the quality of their projects. But there is also no doubt that as commercial banking became more professionalized and more regulated, lending practices changed in ways that were not always conducive to the finance of SMEs. To secure long-term credit, for example, borrowers typically had to pledge collateral whose value was at least twice the amount of the loan (Snowden, 1995; Hoffman, Postel-Vinay, and Rosenthal, 2000). To secure short-term credit, they often had to maintain compensating balances in their deposit accounts, as well as to meet increasingly rigid quantitative standards of creditworthiness (Collins, 1991; Lamoreaux, 1994).

mainly affected the large industrial enterprises that otherwise might have used the exchange to raise equity. Similarly, the anti-branching regulations that many state governments imposed in the U.S. kept financial institutions too small to meet the needs of large-scale businesses (Calomiris, 1995; Davis, 1966). Even these problems can be exaggerated, however. There is considerable evidence that firms denied access to the Paris Bourse found an effective substitute in the coulisse (Plache, 1999). Moreover, William Doyle (1991 and 2000) has argued, based on his detailed research on the U.S. sugar and meat-packing industries, that large firms had no difficulty financing investment out of retained earnings and short-term sources of funds. They had to turn to the equity markets when they organized mergers because bargaining problems made it difficult to fund the necessary acquisitions in any other way. But after the mergers were completed, they reverted to traditional means of financing working capital and even investment. 
Hence, as local banks grew (or merged) into large modern financial institutions, entrepreneurs devised new types of financial intermediaries to service the SME part of the market. This process is especially apparent in the United States where the National Banking Acts of the early 1860s transformed virtually overnight banks that had served the needs of their community's businesses into more professional institutions with lending standards enforced by a national system of bank examiners (Lamoreaux, 1994). To fill the resulting void, local business people founded new state banks, savings institutions, building and loan associations, and trust companies. The latter were especially important because their charters enabled them to combine investment with commercial banking functions, while the laxer regulatory restrictions to which they were held enabled them to compete effectively with more established commercial banks for deposits (Barnett, 1911; Neal, 1971; White, 1982 and 1983, ch.1; Snowden, 1995 and 1997). During the late nineteenth and early twentieth centuries, for example, when Cleveland, Ohio, was a center of start-up enterprises in electricity, chemicals, steel, automobiles, and other second-industrial-revolution technologies, local entrepreneurs founded a dozen trust companies, as well as scores of savings institutions and buildings and loans (Lamoreaux, Levenstein, and Sokoloff, 2006).

We do not wish to minimize the problems that small- and medium-size firms faced in raising capital. Nonetheless, our reading of the historical record leads us to emphasize the positive: the alacrity with which, in this generally permissive regulatory environment, financial intermediaries emerged to serve SMEs wherever there was sufficient local demand; and the high degree of creativity that the entrepreneurs who founded these intermediaries exhibited as they innovated around such regulatory barriers 
as existed, built on preexisting institutional structures, and responded to local factor endowments and other special conditions.

\section{Financial Deserts}

So far our argument that the development of financial institutions was largely demand driven has been based on an examination of success stories. Even in Western Europe and North America, however, there were places that could be characterized as economic deserts. Instead of accumulating or attracting capital, these regions exported labor. They also generally suffered from a lack of financial intermediation. In this section, we consider whether restrictive chartering or regulatory policies might have inhibited the development of financial services in these regions. Although information about many of these areas is difficult to find, the available evidence suggests, to the contrary, that differences in demand explain much of the regional heterogeneity in financial activity.

One financial desert for which we have quite a bit of information is the area of Central France that includes the départements of Aveyron, Cantal, Coreze, Lot, and Lozere (henceforth, and by exaggeration, the Massif Central). This region lacked natural endowments, was located far from markets, and had a population that was not particularly well educated. Low tax payments and the short height of the region's conscripts suggest that the area was poor in the 1840s, and the area remained far below average according to a number of development indicators at the end of the century. Although there was some manufacturing on the fringes of the region (most famously Porcelain in Limoges and Michelin tires in Clermont Ferrand), as late as 1898 only 
22,000 of its people worked in manufacturing. Relative to population, that figure was a quarter of the French average. There was also significant out migration. Although the French population grew by 16 percent from 1840 to 1900 , these départements lost more than 4 percent of their population over the same period (Annuaire Statistique de la France, 1899).

It is possible to measure the diffusion of various kinds of financial intermediaries in this area compared to the rest of France. The oldest such institutions were private commercial banks, set up as sole proprietorships or partnerships of one form or another. ${ }^{12}$ During the period 1820 to 1850 , there was a massive increase in private banks throughout the country, but in the Massif Central they were much slower to form. On a per capita basis there were half as many private banks in this region in 1829 as in the country as a whole (see Table 2). Over the rest of the century the gap closed, so that by 1898 there were roughly as many bank offices per capita in the Massif Central as elsewhere. But because the rate of population growth was much slower in this region, the growth in the number of bank offices was actually quite modest. More importantly, banks in the Massif Central were also small relative to the national average. Although there were no reporting requirements for private banks, we can estimate the extent of their activity by looking at the magnitude of their discounts at regional offices of the Banque de France at the end of the century. ${ }^{13}$ In the Massif Central, the Banque de France's discounts per

\footnotetext{
${ }^{12}$ Bank offices are enumerated in Annuaire Didot-Bottin, various years.

${ }^{13}$ Because the nation's large corporate banks did not use the Banque's branch offices, these discounts provide an index of the activities of local private banks. Annuaire Statistique de la France (1899).
} 
capita were only 28 percent of the non-Paris national average, suggesting that the region's low level of private banking primarily resulted from a low level of demand.

During the 1870s France's five big modern banks began to open offices throughout the country. The Banque de France and the Crédit Foncier were government controlled but mostly privately owned; the Crédit Lyonnais, Comptoir National d'Escompte de Paris, and Société Générale were private corporations. As Table 2 shows, there were only two thirds as many branches of these large banks in the Massif Central as in the rest of the country. Moreover, the Banque de France and the Crédit Foncier, which were required by law to have at least one branch per département, accounted for ten of the sixteen branches in the region. We have already seen that the Banque de France did little business in the Massif Central, and that was true for the Crédit Foncier as well—just opening a branch was not sufficient to create a demand for its services. The French government also mandated that every canton (there were two dozen or so in each département) have at least one branch of a savings bank (caisse d'épargne). As a result, there were as many caisses in the Massif Central as elsewhere on a per capita basis. But the branches held far fewer accounts (Annuaire Statistique de la France, 1899).

The requirement that state-controlled intermediaries serve all of France undoubtedly increased access to credit somewhat in the Massif Central. On the whole, however, it is likely that the main effect of these policies was to encourage local savings. Government initiatives like the branching requirements imposed on the Banque de France, the Crédit Foncier, or the caisses d'épargnes did not involve any significant commitment of public resources; in general the French government left finance to the private sector. Regulation was sufficiently light, moreover, that it did not inhibit entry 
into financial services, even in this remote area with weak demand. As we have seen, private banks did enter the area in the first two thirds of the century, and there was also some expansion by larger corporate banks later on.

Because scholars have disproportionately focused their attention on areas that developed successfully rather than those that were left behind, we have much less information about other financial deserts in the North Atlantic Core. But the available anecdotal evidence confirms our sense that such deserts existed because there was little demand for financial services in these regions, not because governments inhibited the spread of the banking system or of other financial intermediaries. In the earlynineteenth-century U.S., for example, the New England states' generous chartering policies led many rural towns to create banks, even though there was not enough local business to keep their funds profitably employed. In order to pay dividends to their stockholders, the directors of institutions such as the Strafford Bank of Dover, New Hampshire, and the Mendon Bank of Mendon, Massachusetts, had to travel long distances to urban financial centers to buy commercial paper. Not surprisingly, given the serious adverse selection problems they faced when operating in these distant markets, they were relatively more likely to fail or to decide voluntarily to dissolve. In Maine, the most undeveloped of the New England states, not only did about a dozen banks fail, but 20 out the 71 banks chartered between 1820 and 1838 never even opened their doors (Lamoreaux, 1994, 18, 55, 64).

In the early nineteenth century, the various U.S. states differed in their willingness to charter banks, but private banks seem to have flourished wherever regulations were tight but banking services were needed (Sylla, 1976). We do not mean to claim that 
regulatory restrictions never had any adverse effects on the financial system. But because the financial intermediaries that catered to SMEs were local institutions that drew on local sources of information and local sources of capital, they were generally better able to maneuver around such interventions than the grand institutions of modern finance.

\section{Summary and Implications}

As we have argued above, SMEs in the North Atlantic Core primarily secured finance through local institutions that emerged endogenously to meet their needs. These local intermediaries had two important weaknesses. First, they discriminated among potential entrepreneurs on the basis of a variety of criteria that may have been only weakly related to the expected returns of their projects. Second, they were poorly diversified from a geographic or sectoral view point, and as a result, faced serious difficulties withstanding crises. In the North Atlantic Core, however, these weaknesses were not as serious as they might otherwise have been. The effects of discrimination were offset at least in part by the basically competitive nature of these capital markets, and the ties that local intermediaries formed with national financial institutions helped them to weather area-specific shocks. Moreover, these local financial intermediaries had significant strengths. Because they could tap into sources of information that large-scale, "modern," financial institutions found too costly to exploit, they were able to provide credit to firms that were either too small or too young otherwise to obtain finance. They also raised the return to savings for households in their vicinity, and as a consequence, were able to mobilize substantial new resources for economic development. 
The financial institutions that sprang up to serve SMEs throughout the North Atlantic Core were often local in their form of organization as well as in their geographic scope. Indeed, the most striking feature of these institutions may well have been their diversity. Although some types of intermediaries, for example commercial banks, were ubiquitous, even these might take different forms in different regions—in some places organizing as corporations, in some places as various kinds of partnerships, in some places as sole proprietorships. Other institutions had much more limited diffusion. For instance, credit cooperatives do not seem to have been very important west of the Rhine.

The governments of the North Atlantic Core did not play a significant role in the development of these local capital markets. Rather, for the most part they left it to private individuals and firms to solve the financing needs of manufacturing enterprises in general and SMEs in particular. This is not to say that government policies had no effect on these markets. To the contrary, the different legal and political frameworks of the various countries of the North Atlantic Core shaped the development of local financial institutions in path dependent ways. Inevitably, each of these frameworks had both advantages and offsetting disadvantages that often stemmed from a common source. For example, the same types of political pressures that led to easy entry into banking in the northeastern U.S. also led to restrictions on branch banking. None of these drawbacks, however, appear to have been sufficiently serious to prevent local financial institutions from emerging wherever there was sufficient demand for their services.

As Table 1 showed, SMEs in developing economies today have recourse to a variety of different sources of finance, just like those in the North Atlantic Core during the nineteenth century. If we break the data in the table down by firm size, rather than 
country of origin, we observe the classic pattern that reliance on banks and similar kinds of formal intermediaries increases with the size of firms, whereas dependence on informal sources of funds decreases with size (see Table 3). As was the case in the nineteenth century, few firms in any size category raise capital for new investment by issuing equity. Moreover, if we break the data down by organizational form, adoption of the corporate form does not make it any more likely that firms will raise capital in this way (see Table 4). Even today SMEs simply do not use the equity markets to raise funds, but rather, like their nineteenth-century counterparts, secure external finance mainly through some form of credit.

The problem remains, however, of the relative lack of SMEs in these economies-a problem that, as we have seen, is most acute in the poorest countries with the least developed financial systems. Our historical analysis of the North Atlantic Core suggests that one possible explanation for the apparent dearth of financial support for SMEs is that these countries are like the Massif Central—-that is, they are financial deserts because there is little demand for this type of finance. It may simply be that SMEs in developing economies today, unlike their historical counterparts through much of the North Atlantic Core, operate by dint of their position in the world economy too far from the productivity frontier to be competitive. But it is, of course, also possible that there are regulatory or other institutional barriers that prevent local financial intermediaries from emerging or that stifle the demand for these kinds of financial services.

Turning once again to history, but this time to countries outside the North Atlantic Core, the case of Mexico would seem to support the view that regulatory barriers can 
prevent financial institutions from developing to serve SMEs. Under the dictatorship of Porfirio Díaz during the late nineteenth and early twentieth centuries, entry into banking was severely limited. The nation's largest bank, the Banco Nacional de México, whose directors belonged to Díaz's inner clique, obtained a variety of special privileges, including exclusive status as the government's own bank, a monopoly on note issue, and the sole right to establish branches, that gave it a big advantage over other banks. As if those boons were not enough to solidify the Banco Nacional's position, competing institutions faced extraordinarily high minimum capital and reserve requirements, and new banks had to obtain authorization from both the Congress and from the Díaz's administration in order to form (Haber, 1991, 1997, and 2006). That these entry barriers indeed had detrimental consequences for the growth of SMEs is suggested by the experience of the textile industry. Firms whose proprietors or directors were not on the boards of the few existing banks were seriously disadvantaged in access to credit, and as a result, grew more slowly than firms with direct connections to banks. As a result, despite the absence of significant economies of scale, Mexico's textile industry was much more highly concentrated than that of the U.S. or other countries where access to credit was not so severely rationed (Maurer and Haber, 2004).

Not all Latin American governments played such an interventionist role in financial markets, however. Some (for example, Chile, Colombia, and Peru) more closely resembled those of the North Atlantic Core in their essentially laissez faire stance toward the financial system (Zegarra, 2005; Islas Rojas, 2005). All these countries had considerably more banks per capita than Mexico for most of the half century preceding World War I. Nonetheless, compared to the countries of the North Atlantic Core, their 
banking sectors look underdeveloped. As Luis Zegarra (2005) has argued, this difference seems to have resulted from the relative absence of demand for financial services. A combination of high levels of wealth inequality and the general poverty of the population meant that there just was not much opportunity for small local financial intermediaries to make money (see also Hoffman, Postel-Vinay, and Rosenthal, 2005).

It thus seems that, even where the regulatory environment was supportive, there were factors on the demand side that limited financial development across Latin America. Again, such a finding does not necessarily imply that better designed institutions could not have helped to remedy the situation or that there were no potentially beneficial policies that could have assisted SMEs in these countries. Similarly, it does not necessarily follow that governments cannot improve financial conditions for SMEs in developing countries today. Certainly, interventions that address underlying informational and monitoring problems can expand financial services to SMEs. For example, Powell et al. (2005) argue that, because private financial institutions in developing economies want to protect their own informational rents, they are more willing to share negative data about borrowers than information about successful repayment. Thus, publicly owned credit registries can improve information flows by making positive information available. Based on data for Argentina, Brazil, and Mexico, those authors claim that public provisions of such facilities can increase the proportion of the population with access to credit by as much as 50 percent. This is an area, moreover, where technological advance has been important. Not only can the information in such registries be disseminated cheaply and quickly to lenders, but modern credit scoring models may provide a less costly way of using personal information than traditional 
forms of relationship lending (Frame, Padhi, and Woosley, 2004; Berger, Frame, and Miller, 2005).

Of course, registries can only benefit borrowers with a credit history, and thus many potential entrepreneurs without collateral would still lack access to credit. Successful policy interventions for that group would require different solutions to selection and monitoring problems. Perhaps the most promising is joint liability loans through microfinance institutions, where loans typically are granted to individuals but liability for repayment extends to a small group of borrowers, who then have the incentive to monitor other group members (like the German credit cooperatives of the late nineteenth century). The amount of such finance that is currently available is modest. Moreover, most of the enterprises that obtain credit from these institutions are smaller than the SMEs that are the focus of this paper. But this type of lending has the potential to enable borrowers to establish a track record that would enable them to secure larger loans based on individual liability in the future (Armendáriz de Aghion and Morduch, 2005, ch. 4; Cull, Demirgüç-Kunt, and Morduch, 2005).

A final set of policy alternatives might focus on barriers that prevent small entrepreneurs from organizing their businesses as formal legal entities. Recent research on the costs of doing business in developing countries suggests that it may pay enterprise owners to remain informal, which could limit their access to external finance and thus their growth opportunities (World Bank, 2004). Removing some of the obstacles associated with registering a business and reducing the costs of complying with regulation, to say nothing of eliminating the corruption that can make formal businesses the victims of expropriation, should not only relax the financial constraints SMEs face 
but also stimulate the demand for the kinds of local institutions that emerged endogenously throughout the North Atlantic Core.

\section{References}

Annuaire Didot-Bottin, 1829, 1840, 1899. Firmin Didot, Paris.

Annuaire Statistique de la France, 1899. Institut national de la statistique et des études économiques, Paris.

Armendáriz de Aghion, B., Morduch, J., 2005. The Economics of Microfinance. MIT Press, Cambridge.

Balleisen, E.J., 2001. Navigating Failure: Bankruptcy and Commercial Society in Antebellum America. University of North Carolina Press, Chapel Hill.

Barnett, G.E., 1911. State Banks and Trust Companies Since the Passage of the NationalBank Act. Government Printing Office, Washington, D.C.

Baskin, J.B., Miranti, P.J., Jr., 1997. A History of Corporate Finance. Cambridge University Press, New York.

Baten, J., 2001. Produktivitätsvorteil in kleinen und mittelgroßen Industrieunternehmen, Sicherheit in Großunternhmen? Die Gesamtfaktorproduktivität um 1900. Tübinger Diskussionsbeitrag 217.

Beck, T., Demirgüç-Kunt, A., Maksimovic, V., 2004. Financing patterns around the world: Are small firms different? World Bank mimeo.

Beck, T., Levine, R., Loayza, N., 2000. Finance and the sources of growth. Journal of Financial Economics, 58, 261--300. 
Benston, G.J., 1994. Universal banking. Journal of Economic Perspectives 8, 121--143.

Berger, A.N., Frame, W.S., Miller, N.H., 2005. Credit scoring and the availability, price, and risk of small business credit. Journal of Money, Credit, and Banking 37, 191-222 .

Best, M.H., Humphries, J., 1986. The city and industrial decline, in: Elbaum, B., Lazonick, W. (Eds.), The Decline of the British Economy. Clarendon Press, Oxford, pp. 223--239.

Bodenhorn, H., 2000. A History of Banking in Antebellum America. Financial Markets and Economic Development in an Era of Nation-Building. Cambridge University Press, New York.

Bodenhorn, H., 2003. State Banking in Early America: A New Economic History. Oxford University Press, New York.

Bonnin, H., 2004. Histoire de Banques: Crédit du Nord, 1848-2003. Hervas, Paris.

Brennan, T., 1997. Burgundy to Champagne: The Wine Trade in Early Modern France. Johns Hopkins University Press, Baltimore.

Calomiris, C.W., 1995. The costs of rejecting universal banking: American finance in the German mirror, 1870-1914, in: Lamoreaux, N.R., Raff, D.M.G. (Eds.), Coordination and Information: Historical Perspectives on the Organization of Enterprise. University of Chicago Press, Chicago, pp. 257--315.

Cameron, R. (Ed.), 1972. Banking and Economic Development: Some Lessons of History. Oxford University Press, New York. 
Capie, F., Collins, M., 1992. Have the Banks Failed British Industry? An Historical Survey of Bank/Industry Relations in Britain, 1870-1990. Institute of Economic Affairs, London.

Chassagne, S., 1991. Le Cotton et Ses Patrons; France, 1760-1840. Ecole des Hautes Etudes en Sciences Sociales. Paris.

Collins, M., 1991. Banks and Industrial Finance in Britain, 1800-1939. Macmillan, Houndmills, Basingstoke, Hampshire.

Collins, M., 1998. English bank development within a European context, 1870-1939. Economic History Review 51, 1--24.

Compte général de l'administration de la justice civile et commerciale, 1919-1933. Imprimerie Nationale, Paris.

Compte général de l'administration de la justice civile et commerciale et criminelle, 1933-1960. Imprimerie Nationale, Paris.

Compte général de l'administration de la justice criminelle et de la justice civile et commerciale, 1961-1980. Documentation Française, Paris.

Cottrell, P.L., 1979. Industrial Finance, 1830-1914. Methuen, London.

Cottrell, P., Newton, L., 1999. Banking liberalization in England and Wales, 1826-1844, in: Sylla, R., Tilly, R., Tortella, G. (Eds.), The State, the Financial System, and Economic Modernization. Cambridge University Press, Cambridge, pp. 75--117.

Cull, R., Demirgüç-Kunt, A., Morduch, J., 2005. Financial performance and outreach: A global analysis of leading microbanks.” World Bank mimeo. 
Da Rin, M., 1996. Understanding the development of the German kreditbanken, 1850-

1914: An approach from the economics of information. Financial History Review 3, 29--47.

Daumard, A., 1973. Les Fortunes Francaises au XIXe Siecle: Enquête sur la Répartition et la Composition des Capitaux Privés à Paris, Lyon, Lille, Bordeaux et Toulouse d'après l'Enregistrement des Déclarations de Succession. Mouton, Paris.

Davis, L.E., 1966. The capital markets and industrial concentration: The U.S. and the U.K., a comparative study. Economic History Review 19, 255--272.

Davis, L.E., Gallman, R.E., 1978. Capital formation in the United States during the nineteenth century, in: Mathias, P., Postan, M.M. (Eds.), The Cambridge Economic History of Europe, Vol. VII, The Industrial Economies: Capital, Labour, and Enterprise, Part 2, The United States, Japan, and Russia. Cambridge University Press, Cambridge. pp. 1--69.

Davis, L.E., Gallman, R.E., 2001. Evolving Financial Markets and International Capital Flows: Britain, the Americas, and Australia, 1870-1914. Cambridge University Press, New York.

Doyle, W.M., 1991. The evolution of financial practices and financial structures among American manufacturers, 1875-1905: Case studies of the sugar refining and meat packing industries.” Unpublished Ph.D. Dissertation, University of Tennessee.

Doyle, W.M., 2000. Capital structure and the financial development of the U.S. sugarrefining industry, 1875-1905. Journal of Economic History 60, 190--215.

Edwards, J., Ogilvie, S., 1996. Universal banks and German industrialization: A reappraisal. Economic History Review 49, 427--46. 
Feldenkirchen, W., 1981. The banks and the steel industry in the Ruhr: Developments in relations from 1873 to 1914." German Yearbook on Business History 1981, 27-51.

Feldenkirchen, W., 1991. Banking and economic growth: Banks and industry in Germany in the nineteenth century and their changing relationship during industrialization, in: Lee, W. R. (Ed.), German Industry and German Industrialisation: Essays in German Economic and Business History in the Nineteenth and Twentieth Centuries. Routledge, London, pp. 116--143.

Fohlin, C., 1997a. Bank securities holdings and industrial finance before World War I: Britain and Germany compared. Business and Economic History 26, 463--475.

Fohlin, C., 1997b. Universal banking networks in pre-war Germany: New evidence from company financial data. Research in Economics 51, 201--225.

Fohlin, C., 1998. Relationship banking, liquidity, and investment in German industrialization. Journal of Finance 53, 1737--1758.

Fohlin, C., 1999a. The rise of interlocking directorates in imperial Germany. Economic History Review 52, 307--333.

Fohlin, C., 1999b. Universal banking in pre-World War I Germany: Model or myth? Explorations in Economic History 36, 305--343.

Frame, W.S., Padhi, M., Woosley, L., 2004. Credit scoring and the availability of small business credit in low- and moderate-income areas. Financial Review 39, 35--54.

Franks, J., Mayer, C., Rossi, S., 2005. Spending less time with the family: The decline of family ownership in the UK, in: Morck, R. (Ed.), The History of Corporate 
Governance Around the World: Family Business Groups to Professional Managers. University of Chicago Press, Chicago, forthcoming.

Gelderblom, O., Jonkers, J., 2004. Completing a financial revolution: The finance of the Dutch East India trade and the rise of the Amsterdam capital market, 1595-1612. Journal of Economic History 64, 641-672.

Gerschenkron, A., 1962. Economic Backwardness in Historical Perspective: A Book of Essays. Harvard University Press, Cambridge, Mass.

Ghatak, M., Guinnane, T.W., 1999. The economics of lending with joint liability: Theory and practice. Journal of Development Economics 60, 195--228.

Goldsmith, R.W., 1969. Financial Structure and Development. Yale University Press, New Haven.

Guinnane, T.W., 1997. Regional organizations in the German cooperative banking system in the late $19^{\text {th }}$ century. Research in Economics 51, 251--274.

Guinnane, T.W., 2001. Cooperatives as information machines: German rural credit cooperatives, 1883-1914. Journal of Economic History 61, 366--389.

Guinnane, T.W., 2002. Delegated monitors, large and small: Germany's banking system, 1800-1914. Journal of Economic Literature 40, 73--124.

Haber, S.H., 1991. Industrial concentration and the capital markets: A comparative study of Brazil, Mexico, and the United States, 1830-1930. Journal of Economic History 51, 559--580.

Haber, S.H., 1997. Financial markets and industrial development: A comparative study of governmental regulation, financial innovation, and industrial structure in Brazil and Mexico, 1840-1930, in: Haber, S. (Ed.), How Latin America Fell Behind: 
Essays on the Economic Histories of Brazil and Mexico, 1800-1914. Stanford University Press, Stanford. [p. 146--178.

Haber, S.H., 2006. It wasn't all Prebisch's fault: The political economy of Latin American industrialization, in: Thomas, V.B. (Ed.), The Cambridge Economic History of Latin American. Cambridge University Press, New York, forthcoming.

Hautcoeur, P., 1994. Le Marché Boursier et le Financement des Entreprises Francaises (1890-1939). Doctoral dissertation, Paris 1, Paris.

Herrigel, G., 1996. Industrial Constructions: The Sources of German Industrial Power. Cambridge University Press, New York.

Hirsch, J., 1991. Les Deux Rêves du Commerce: Entreprise et Institution Dans la Région Lilloise (1780-1860). Ecole des Hautes Etudes en Sciences Sociales, Paris.

Hoffman, P., Postel-Vinay, G., Rosenthal, J., 2000. Priceless Markets: The Political Economy of Credit in Paris, 1660-1870. Chicago, University of Chicago Press. Hoffman, P., Postel-Vinay, G., Rosenthal, J., 2003. No exit: Notarial bankruptcies and the evolution of financial intermediation in nineteenth century Paris, in: Engerman, S.L., Hoffman, P.T., Rosenthal, J., Sokoloff, K.L. (Eds.), Finance, Intermediaries, and Economic Development. Cambridge University Press, New York, pp. 75--108.

Hoffman, P., Postel-Vinay, G., Rosenthal, J., 2004. Révolution et évolution: Les marchés de crédit notarié en France 1780-1840. Annales ESC 59, 387--424. 
Hoffman, P., Postel-Vinay, G., Rosenthal, J., 2005. Surviving Large Losses: Financial Crises, the Middle Class, and the Development of Capital Market. Harvard University Press, Cambridge, Mass., forthcoming.

Islas Rojas, G., 2005. Does regulation matter? An analysis of Chilean corporate charters in the nineteenth century. Unpublished paper.

Kennedy, W.P., 1987. Industrial Structure, Capital Markets and the Origins of British Economic Decline. Cambridge University Press, Cambridge.

Lamoreaux, N.R., 1994. Insider Lending: Banks, Personal Connections, and Economic Development in Industrial New England. Cambridge University Press, New York. Lamoreaux, N.R., Levenstein, M., Sokoloff, KL., 2006. Financing invention during the Second Industrial Revolution: Cleveland, Ohio, 1870-1920, in: Lamoreaux, N.R., Sokoloff, K. L. (Eds.), The Financing of Innovation in Historical Perspective. MIT Press, Cambridge, Mass., forthcoming.

Lamoreaux, N.R., Rosenthal, J., 2005. Legal regime and contractual flexibility: A comparison of business's organizational choices in France and the United States during the era of industrialization. American Law and Economics Review 7, 28-61.

Lamoreaux, N.R., Rosenthal, J., 2006. Corporate governance and the plight of minority shareholders in the United States before the Great Depression, in: Glaeser, E., Goldin, C. (Eds.), Corruption and Reform. University of Chicago Press, Chicago, forthcoming.

Lehnardt, A., 1955. Quelques Points de Comparaison Entre le Régime Français et le Régime Allemand des Sociétés à Responsabilité Limitée. Anger, Lanion. 
Lemercier, C., 2003. Un Si Discret Pouvoir: Aux Origines de la Chambre de Commerce de Paris, 1803-1853. Découverte, Paris.

Lescure, M., 1999. Small- and medium-size industrial enterprises in France, 1900-1975, in: Odaka, K., Sawai, M. (Eds.), Small Firms, Large Concerns: The Development of Small Business in Comparative Perspective. Oxford University Press, Oxford, pp. 140--167.

Levine, R., 1997. Financial development and economic growth: Views and agenda. Journal of Economic Literature 35, 688--726.

Levine, R., 2005. Finance and growth: Theory and evidence, in: Aghion, P., Durlauf, S. (Eds.), Handbook of Economic Growth. Elsevier Science, Amsterdam, forthcoming.

Levine, R., Loayza, N., Beck, T., 2000. Financial intermediation and growth: Causality and causes. Journal of Monetary Economics 46, 31--77.

Lévy-Leboyer, M., 1964. Les Banques Européenes et l’Industrialisation Internationale dans la Première Moitié du XIX ${ }^{\mathrm{e}}$ Siècle. Presses Universitaires de France, Paris.

Madison, J.H., 1974. The evolution of commercial credit reporting agencies in nineteenth-century America. Business History Review 48, 164--186.

Martin, J.G., 1898. A Century of Finance: Martin's History of the Boston Stock and Money Markets. Privately printed, Boston.

Maurer, N., Haber, S., 2004. Related lending and economic performance: Evidence from Mexico. Unpublished paper.

Meissner, C.M., 2005. Voting rules and the success of connected lending in 19th century New England banks. Explorations in Economic History, forthcoming. 
Michie, R.C., 1999. The London Stock Exchange: A History. Oxford University Press, Oxford.

Navin, T.R., Sears, M.V. 1955. The rise of a market for industrial securities, 1887-1902. Business History Review 29, 105--138.

Neal, L., 1971. Trust companies and financial innovation, 1897-1914. Business History Review 45, 35--51.

Neal, L., 1994. The finance of business during the Industrial Revolution, in: Floud, R., McCloskey, D. (Eds.), The Economic History of Britain since 1700, Vol. I. Cambridge University Press, Cambridge, pp. 151--181.

Newton, L., 1997. Domestic institutional change: Regional English joint-stock banking, 1826-1880. Unpublished paper.

Norris, J.D., 1978. R. D. Dun \& Co. 1841-1900: The Development of Credit-Reporting in the Nineteenth Century. Greenwood Press, Westport, Conn.

Olegario, R., 2001. Institutions and markets: U.S. credit reporting in historical perspective. Unpublished paper.

Piketty, T., Postel-Vinay, G., Rosenthal, J., 2005. Wealth concentration in a developing economy: Paris and France, 1807-1994. American Economic Review, forthcoming.

Plache, L., 1999. Financial institutions, government policy and industrialization: The development of the French stock market, 1852-1875. Unpublished Ph.D. Dissertation, University of California, Los Angeles.

Pohl, H., 1984. Forms and phases of industry finance up to the Second World War. German Yearbook on Business History 1984, 75--94. 
Pohl, M., 1991. Überlebenschanden fon Unternehmungsgründungen 1870 bis 1918. Zeitschrift für Unternehmensgeschichte 63, 29--47.

Powell, A., Mylenko, N., Miller, M., Majnoni, G., 2004. Improving credit information, bank regulation and supervision: On the role and design of public credit registries. World Bank Policy Research Working Paper 3443.

Riesser, J., 1911. The German Great Banks and their Concentration in Connection with the Economic Development of Germany. Government Printing Office, Washington, D.C.

Snodgrass, D.R., Biggs, T., 1996. Industrialization and the Small Firm: Patterns and Policies. ICS Press, San Francisco.

Snowden, K.A., 1995. The evolution of interregional mortgage lending channels, 18701940: The life insurance-mortgage company connection, in: Lamoreaux, N. R., Raff, D.M.G. (Eds.), Coordination and Information: Historical Perspectives on the Organization of Enterprise. University of Chicago Press, Chicago, pp. 209--247.

Snowden, K.A., 1997. Building and loan associations in the U.S., 1880-1893: The origins of localization in the residential mortgage market. Research in Economics $51,227--250$.

Sylla, R., 1976. Forgotten men of money: Private bankers in early U.S. history. Journal of Economic History 36, 173--188.

Thomas, W.A., 1973. The Provincial Stock Exchanges. Cass, London.

Tilly, R., 1966. Financial Institutions and Industrialization in the Rhineland, 1815-1870. University of Wisconsin Press, Madison. 
Tilly, R.H., 1986. German banking, 1850-1914: Development assistance for the strong. Journal of European Economic History 15, 113--152.

Tilly, R.H., 1989. Banking institutions in historical and comparative perspective: Germany, Great Britain and the United States in the nineteenth and early twentieth century. Journal of Institutional and Theoretical Economics 145, 189-209.

Tilly, R., 1992. An overview on the role of the large German banks up to 1914, in: Cassis, Y. (Ed.), Finance and Financiers in European History, 1880-1960. Cambridge University Press, Cambridge. pp. 93--112.

Wellhöner, V., Wixforth, H., 2003. Finance and industry, in: Ogilvie, S., Overy, R. (Eds.), Germany: A New Social and Economic History, Vol. III, Since 1800. Arnold, London, pp. 152--191.

Wengenroth, U., 1994. Enterprise and Technology: The German and British Steel Industries, 1865-1895, trans. Sarah Hanbury Tenison. Cambridge University Press, Cambridge.

Wengenroth, U., 1999. Small-scale business in Germany: The flexible element of economic growth, in: Odaka, K., Sawai, M. (Eds.), Small Firms, Large Concerns: The Development of Small Business in Comparative Perspective. Oxford University Press, Oxford, pp. 117--139.

White, E.N., 1982. The political economy of banking regulation, 1864-1933. Journal of Economic History 42, 33--40.

White, E.N., 1983. The Regulation and Reform of the American Banking System, 19001929. Princeton University Press, Princeton. 
World Bank., 2004. Doing Business in 2004: Understanding Regulation. Oxford University Press and the World Bank, Oxford and Washington, D.C.

Wright, R.E., 1999. Bank ownership and lending patterns in New York and Pennsylvania, 1781-1831. Business History Review 73, 40--60.

Zegarra, L., 2005. Institutions, economic development and early banking in Latin America, 1850-1930. Unpublished paper. 
Table 1: Sources of Funds for Small Firms, By Country

\begin{tabular}{|c|c|c|c|c|c|c|c|c|}
\hline Country & (2) & $\begin{array}{l}\text { Internal } \\
\text { Funds, } \\
\text { Retained } \\
\text { Earnings } \\
\\
\text { (3) } \\
\end{array}$ & $\begin{array}{c}\text { Family, } \\
\text { Friends, } \\
\text { Informal } \\
\text { Sources } \\
\text { (4) }\end{array}$ & Banks & $\begin{array}{l}\text { Equity, } \\
\text { Sale of } \\
\text { Stock } \\
\\
(6) \\
\end{array}$ & $\begin{array}{c}\text { Leasing, Trade } \\
\text { Credit, Credit } \\
\text { Card, Development } \\
\text { funds } \\
\text { (7) }\end{array}$ & Total & $\begin{array}{l}\text { Share of } \\
\text { Firms } \\
\text { with No } \\
\text { External } \\
\text { Finance } \\
\text { (9) }\end{array}$ \\
\hline Albania & 70 & 77.4 & 9.1 & 5.3 & 0 & 3.6 & 95.4 & 62.9 \\
\hline Armenia & 59 & 87.5 & 5.9 & 1.9 & 0 & 2.7 & 98 & 72.9 \\
\hline Azerbaijan & 59 & 81.8 & 5.3 & 1.5 & 0 & 7.1 & 95.7 & 71.2 \\
\hline Bangladesh & 175 & 67.4 & 7.8 & 20.2 & 0.3 & 3.5 & 99.2 & 40.6 \\
\hline Belarus & 51 & 76.8 & 7.8 & 6.3 & 0 & 5.7 & 96.6 & 56.9 \\
\hline Bosnia & 24 & 69.2 & 4.2 & 6.6 & 0 & 4.2 & 84.2 & 50.0 \\
\hline Brazil & 686 & 59 & 3.2 & 14.1 & 3.4 & 18.1 & 97.8 & 44.3 \\
\hline Bulgaria & 56 & 68.9 & 10.4 & 6.4 & 2.2 & 4.9 & 92.8 & 58.9 \\
\hline Croatia & 26 & 46.3 & 2.9 & 18.2 & 7.6 & 8.4 & 83.4 & 19.2 \\
\hline Czech Rep & 62 & 46.6 & 6.6 & 12.3 & 6.7 & 14.8 & 87 & 32.3 \\
\hline Ecuador & 131 & 45.7 & 7.8 & 24.1 & 3.5 & 16.6 & 97.7 & 34.4 \\
\hline Estonia & 37 & 53.5 & 0 & 12.6 & 2.7 & 26.3 & 95.1 & 29.7 \\
\hline Ethiopia & 43 & 67.7 & 5.45 & 21.1 & 1 & 2.5 & 97.75 & 51.2 \\
\hline Macedonia & 12 & 75 & 4.2 & 10.8 & 0 & 0 & 90 & 50.0 \\
\hline Georgia & 29 & 71.6 & 3.3 & 9 & 0 & 2.8 & 86.7 & 58.6 \\
\hline Honduras & 132 & 54 & 10 & 23 & 1.8 & 10.1 & 98.9 & 43.2 \\
\hline Hungary & 73 & 51.1 & 2.1 & 7.6 & 17.1 & 9.5 & 87.4 & 34.3 \\
\hline Kazakhstan & 48 & 70.9 & 8.3 & 3.4 & 4.2 & 5.3 & 92.1 & 56.3 \\
\hline Kenya & 63 & 48.6 & 2.5 & 37.7 & 0.4 & 6.7 & 95.9 & 38.1 \\
\hline Kyrgyzstan & 44 & 69.1 & 9.1 & 4.8 & 0 & 6 & 89 & 54.6 \\
\hline Latvia & 23 & 41.4 & 6.1 & 5.1 & 10 & 15.8 & 78.4 & 21.7 \\
\hline Lithuania & 57 & 80.1 & 3.3 & 4.3 & 0 & 7.7 & 95.4 & 66.7 \\
\hline Moldova & 45 & 64.4 & 12.9 & 15.7 & 0 & 7 & 100 & 31.1 \\
\hline Nicaragua & 130 & 68.2 & 6 & 13.2 & 0 & 10.2 & 97.6 & 59.2 \\
\hline Nigeria & 34 & 47.8 & 4.4 & 13.1 & 6.1 & 1.2 & 72.6 & 44.1 \\
\hline
\end{tabular}




\begin{tabular}{|l|l|c|c|c|c|c|c|c|} 
Philippines & 69 & 58.3 & 14.1 & 8.3 & 5.3 & 7.7 & 93.7 & 43.4 \\
Poland & 95 & 58.5 & 0.2 & 11.9 & 0.5 & 13.1 & 84.2 & 43.2 \\
Romania & 69 & 72 & 5 & 9.2 & 1.7 & 8.5 & 96.4 & 59.4 \\
Russia & 126 & 75.7 & 4.4 & 5.2 & 0.6 & 8.9 & 94.8 & 56.4 \\
Slovakia & 42 & 59.6 & 2.6 & 4.1 & 12.4 & 15.8 & 94.5 & 31.0 \\
Slovenia & 54 & 70.3 & 0 & 4.3 & 0 & 10.1 & 84.7 & 24.1 \\
Tajikistan & 46 & 81.6 & 9.9 & 0 & 1.1 & 4.1 & 96.7 & 60.9 \\
Tanzania & 68 & 76.5 & 4.7 & 12.6 & 3.7 & 1 & 98.5 & 66.2 \\
Turkey & 99 & 80.5 & 4.7 & 6.6 & 0.8 & 1.4 & 94 & 62.6 \\
Uganda & 84 & 59.8 & 1.9 & 13.3 & 0 & 13.1 & 88.1 & 66.7 \\
Ukraine & 111 & 80.9 & 9.8 & 2.1 & 0.05 & 4.7 & 97.55 & 68.5 \\
Uzbekistan & 47 & 81.9 & 2.6 & 3 & 0.5 & 5.5 & 93.5 & 72.3 \\
Yugoslavia & 57 & 81 & 4.6 & 5.9 & 4.9 & 3.2 & 99.6 & 64.9 \\
\hline
\end{tabular}

Source: World Bank Investment Climate Surveys (ICS) in 2002-2003. See http://research.worldbank.org/ics/jsp/index.jsp.

Note: Small firms had more than ten but fewer than fifty full-time workers. $\mathrm{N}$ refers to the number of firms surveyed. Columns 3-4 are internal sources of finance; 5-7 are external. Columns 3-7 are summed in column 8 . Column 8 does not equal 100\% because survey respondents were also given the choice of a catch-all category called "other sources of funds." In column 9, we report the share of firms with no access to the sources of funds summarized in columns 5-7. 
Table 2: Financial indicators for France and selected departments

\begin{tabular}{|l|l|l|l|}
\hline Bank Type & $\begin{array}{l}\text { France } \\
\text { Without Paris }\end{array}$ & Massif Central & Ratio \\
\hline Large Bank Branches, 1898 & 18.6 & 12.2 & 0.65 \\
\hline Bank of France Discounts, 1898 & $245 \mathrm{MF}$ & $69 \mathrm{MF}$ & 0.28 \\
\hline Crédit Foncier de France, number of loans, 1853-98 & 1651 & 1534 & 0.92 \\
Crédit Foncier de France, value of loans, 1853-98 & $44.5 \mathrm{MF}$ & $23.1 \mathrm{MF}$ & 0.52 \\
\hline Savings Banks, Branches, 1898 & 15.4 & 15.19 & 0.98 \\
Savings Banks, Accounts, 1898 & 171,000 & 67,000 & 0.39 \\
Savings Banks, Value of accounts, 1898 & $93 \mathrm{MF}$ & $34.3 \mathrm{MF}$ & 0.47 \\
\hline All Bank Branches, 1829 & 18.3 & 10.26 & 0.56 \\
All Bank Branches, 1840 & 32.4 & 21.9 & 0.68 \\
All Bank Branches, 1898 & 70.7 & 64.5 & 0.91 \\
\hline
\end{tabular}

Source: Annuaire statistique de la France, 1899; Annuaire Didot-Bottin, 1829, 1840, 1899.

Note: The Massif Central includes Aveyron, Cantal, Coreze, Lot, and Lozere. France is net of Paris. All values are per million persons. MF is Million Francs. Large banks are the Banque de France, Crédit Foncier de France, Crédit Lyonnais, Comptoir National d'Escompte de Paris, and Société Générale. 
Table 3: Principal Source of External Finance, By Firm Size

\begin{tabular}{|c|c|c|c|c|c|c|}
\hline Size & $\mathrm{N}$ & $\begin{array}{c}\text { Family, Friends, } \\
\text { Informal Sources are } \\
\text { Principal External } \\
\text { Source } \\
\text { (\% of Firms })\end{array}$ & $\begin{array}{c}\text { Banks } \\
\text { are Principal External } \\
\text { Source } \\
(\% \text { of Firms })\end{array}$ & $\begin{array}{c}\text { Equity, Sale of Stock is } \\
\text { Principal External } \\
\text { Source } \\
(\% \text { of Firms })\end{array}$ & $\begin{array}{l}\text { Leasing, Trade Credit, } \\
\text { Credit Card, Develop-ment } \\
\text { funds are Principal } \\
\text { External Source } \\
(\% \text { of Firms })\end{array}$ & $\begin{array}{l}\% \text { of Firms with } \\
\text { No External } \\
\text { Finance }\end{array}$ \\
\hline Micro & 1756 & 14.4 & 9.5 & 3.2 & 8.9 & 64.0 \\
\hline Small & 2988 & 9.4 & 17.6 & 3.0 & 15.4 & 54.6 \\
\hline Medium & 1036 & 4.6 & 25.2 & 2.8 & 16.6 & 50.8 \\
\hline Large & 1036 & 3.6 & 29.5 & 4.1 & 17.0 & 45.9 \\
\hline very large & 1317 & 2.7 & 31.5 & 2.9 & 14.7 & 48.1 \\
\hline
\end{tabular}

Source: See Table 2.

Note: $\mathrm{N}$ is the number of firms. Only firms with complete data for all four forms of external finance are included in the calculations.

Firms for which the category "other" was the leading source of external finance are also excluded. Micro enterprises have less than ten full-time workers; small firms, more than ten but fewer than fifty; medium, more than fifty but less than 100; large, more than 100 but less than 250; and very large, more than 250. 
Table 4: Principal Source of External Finance, By Type of Ownership

\begin{tabular}{|c|c|c|c|c|c|c|}
\hline Ownership Type & $\mathrm{N}$ & $\begin{array}{c}\text { Family, Friends, } \\
\text { Informal Sources are } \\
\text { Principal External } \\
\text { Source } \\
(\% \text { of Firms }) \\
\end{array}$ & $\begin{array}{c}\text { Banks } \\
\text { are Principal External } \\
\text { Source } \\
(\% \text { of Firms })\end{array}$ & $\begin{array}{c}\text { Equity, Sale of Stock } \\
\text { is Principal External } \\
\text { Source } \\
\text { (\% of Firms })\end{array}$ & $\begin{array}{l}\text { Leasing, Trade Credit, } \\
\text { Credit Card, Develop-ment } \\
\text { funds are Principal } \\
\text { External Source } \\
(\% \text { of Firms }) \\
\end{array}$ & $\begin{array}{c}\% \text { of Firms } \\
\text { with No } \\
\text { External } \\
\text { Finance }\end{array}$ \\
\hline Sole Proprietorship & 2030 & 14.9 & 16.8 & -- & 11.2 & 57.0 \\
\hline Partnership & 1351 & 8.6 & 22.7 & 3.6 & 10.7 & 54.4 \\
\hline $\begin{array}{l}\text { Privately Held, Limited } \\
\text { Liability Company }\end{array}$ & 3183 & 5.9 & 22.9 & 3.8 & 19.4 & 48.0 \\
\hline Publicly Listed & 474 & 2.3 & 33.6 & 4.9 & 15.9 & 43.3 \\
\hline Cooperative & 188 & 4.3 & 6.4 & 2.1 & 12.2 & 75.0 \\
\hline
\end{tabular}

Source: See Table 2.

Note: $\mathrm{N}$ is the number of firms. Only firms with complete data for all four forms of external finance are included in the calculations.

Firms for which the category "other" was the leading source of external finance are also excluded. Sole proprietorships that report sales of stock (equity) as a source of external finance are excluded from the calculations. 
Figure 1: Distribution of New Multi-Owner Firms in France 1919-1980

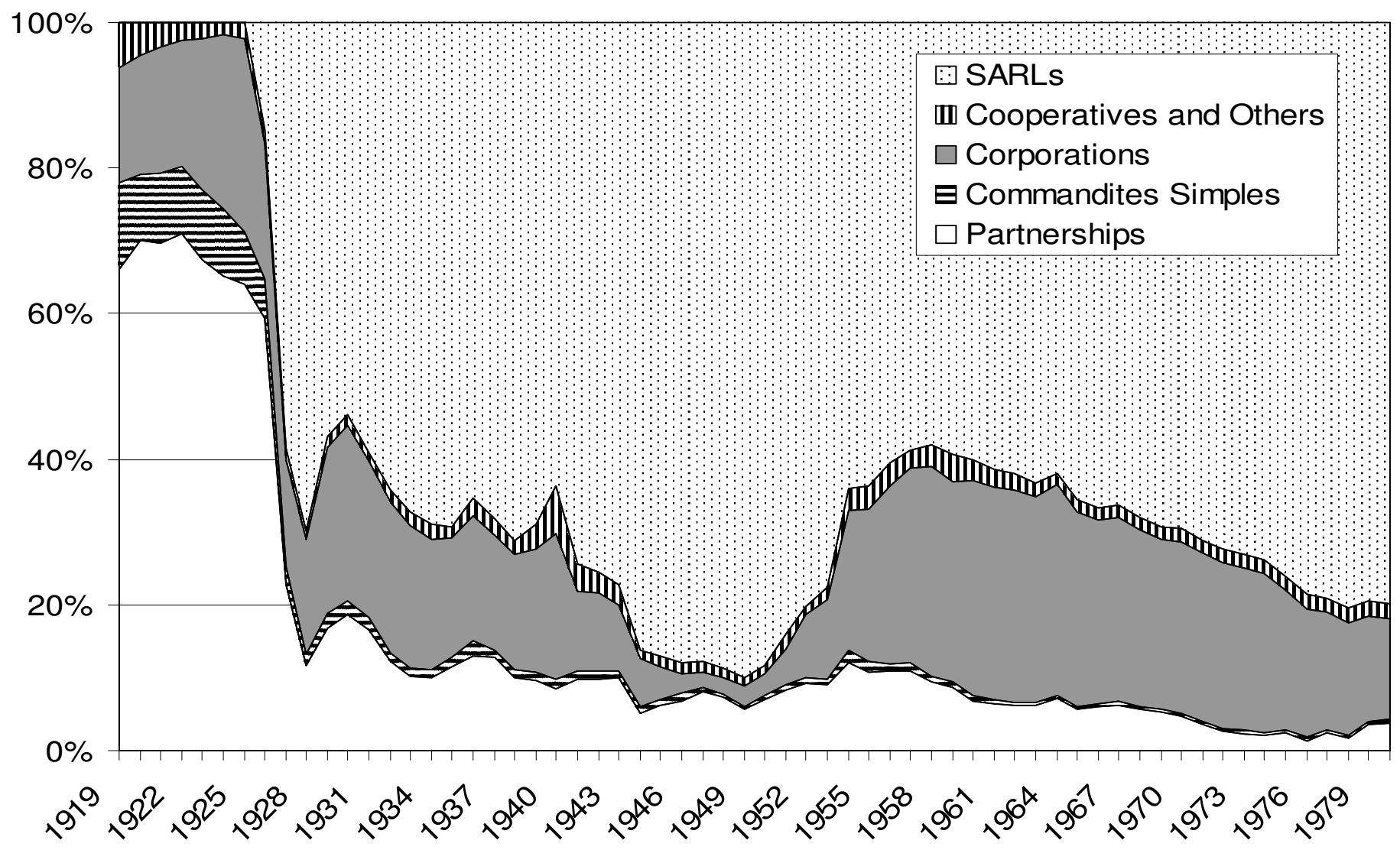


Source: Compte général de l'administration de la justice civile et commerciale, 1919-1933; Compte général de l'administration de la justice civile et commerciale et criminelle, 1933-1960; Compte général de l'administration de la justice criminelle et de la justice civile et commerciale, 1961-1980. 